\title{
Autosomal recessive Kenny-Caffey syndrome
}

INSERM

\section{Source}

INSERM. (1999). Orphanet: an online rare disease and orphan drug data base. Autosomal recessive Kenny-Caffey syndrome. ORPHA:93324

A rare, primary bone dysplasia characterized by prenatal and postnatal growth retardation, short stature, cortical thickening and medullary stenosis of the long bones, absent diploic space in the skull bones, hypocalcemia due to the hypoparathyroidism, small hands and feet, delayed mental and motor development, intellectual disability, dental anomalies, and dysmorphic features, including prominent forehead, small deepset eyes, beaked nose, and micrognathia. 